\title{
Flora of the vascular plants of Oeumsan Mountain (Hongcheon-gun and Hoengseong-gun, Gangwon-do)
}

\author{
Kyung-Ah KIM, Kyeong-Sik CHEON ${ }^{1}$ and Ki-Oug YOO* \\ Department of Biological Sciences, Kangwon National University, Chuncheon 24341, Korea \\ ${ }^{I}$ Department of Biological Science, Sangji University, Wonju 26339, Korea \\ (Received 3 January 2018; Revised 20 February 2018; Accepted 20 March 2018)
}

\begin{abstract}
This study was carried out to investigate the flora of Oeumsan Mountain (Hongcheon-gun and Hoengseong-gun, Gangwon-do) from March of 2016 to September of 2017. The vascular plants were summarized into 509 taxa, including 98 families, 301 genera, 436 species, 4 subspecies, 57 varieties and 12 forms. Among the 509 investigated taxa, 9 Korean endemic, 1 endangered plant, 8 rare plants and 57 floristic regional indicator plants were also included. The naturalized plants encompassed 35 taxa. The percentage of naturalized plants species and the urbanization index were estimated to be $6.9 \%$ and $10.9 \%$, respectively.
\end{abstract}

Keywords: vascular plants, endemic, endangered plants, rare plants, naturalized plants

Hongcheon-gun and Hoengseong-gun at the southwestern part of Gangwon-do, where Oeumsan Mountain (elev. $930 \mathrm{~m}$ ) is located, span $37^{\circ} 37^{\prime}-37^{\circ} 41^{\prime} \mathrm{N}$ and $128^{\circ} 20^{\prime}-128^{\circ} 51^{\prime} \mathrm{E}$, including a mountainous area extended from the Taebaeksanmaek range. They are bordered by Pyeongchang-gun, Gangneung-si, and Yangyang-gun to the east, Gyeonggi-do, Gapyeong-gun and Yangpyeong-gun to the west, Wonju-si and Yeongwol-gun to the south, and Chuncheon-si and Inje-gun to the north. Hongcheon-gun has the largest area with $1,819 \mathrm{~km}^{2}$ among the city (si) and county (gun) in South Korea, in which the Hongcheongang River, a branch of Bukhangang River, flows through urban areas down to the west from the watershed of the Taebaeksanmaek range and merges with the Bukhangang River at Seorak-myeon of Gapyeong-gun in Gyeonggi-do, resulting in a small plain (Hongcheon-gun, 2014). In addition, Hoengseong-gun has an area of $998 \mathrm{~km}^{2}$ and is a mountainous area with many mountains in its northeastern part, but the mountains become small and relatively wide in the southwestern part of this region, making it a fertile plain (Hoengseong-gun, 2015). The two regions are in Youngseo District, west of the Taebaeksanmaek range, which is the main mountain range in South Korea, and has a climate similar to the continental climate due to its location in the central inland of the Korean Peninsula. According to data collected between 2006-2016, the annual mean temperature of these regions ranges from $10.6-12.3^{\circ} \mathrm{C}$. The annual mean precipitation is $703-2,140 \mathrm{~mm}$, in which over $50 \%$ of the annual precipitation falls between July-September (Korea Meterological Administration, 2015).

Oeumsan Mountain, the target area of this survey, spans the region from Hongcheon-eup of Hongcheon-gun to Gonggeun-myeon of Hoengseong-gun in Gangwon-do, is part of the Taebaeksanmaek range, and is bordered by Maehwasan Mountain (elev. $750.8 \mathrm{~m}$ ) to the west, Geummulsan Mountain (elev. $775.5 \mathrm{~m}$ ) to the south, and Mandaesan Mountain (elev. 680.1 m) to the north (Hoengseong-gun, 2015). Previously, Lee and Jeon (2002) and Eom et al. (2009) studied the flora of Oeumsan Mountain; however, these studies were limited in accurate identification of the flora due to the simple survey routes and the number of surveys being just three. Thus, this study was carried out to identify distributions and characteristics of vascular plants based on voucher specimens through surveying vascular plants in the area around Oeumsan Mountain, and then to provide fundamental data for conservation of plant resources.

\footnotetext{
*Author for correspondence: yooko@kangwon.ac.kr
} 


\section{Materials and Methods}

Floristic surveys were conducted a total of 17 times from March 2016 to September 2017, focusing on flowering seasons and fruiting seasons, and the collected voucher specimens were deposited in the herbarium of the Department of Biological Sciences in Kangwon National University (KWNU).

The survey schedule and route are presented in Fig. 1 and Table 1. Plant identification was based on literature of Lee (1996a, 1996b), Lee (2003a, 2003b), Lee (2006a, 2006b), Korea National Arboretum (2008a), and Lee and Lee (2015). In the plant list of family name and scientific names, names of ferns were listed following Lee and Lee (2015) and those of gymnosperms and angiosperms were referred to by names given in a synonymic list of vascular plants in Korea (Korea National Arboretum and The Korean of Plant Taxonomists, 2007). The list of plant species within family was summarized in the alphabetical order. Cultivated species were identified using "(cult.)" after the Korean name. Based on the plant list made, analyses were performed on Korean endemic plants (Chung et al., 2017), endangered wildlife plants (Ministry of Environment, 2012), rare plants (Korea National Arboretum, 2008b), and the floristic regional indicator plants (Ministry of Environment and National Institute of Environmental Research, 2014). Naturalized plants were indexed using data of Lee et al. (2011). Naturalized ratio (Numata, 1975) and the urbanization index (Yim and Jeon, 1980) were calculated using the following equations:
Naturalized ratio (the percent of naturalized plant species) $=$ $\mathrm{S} / \mathrm{N} \cdot \mathrm{V} \times 100$

( $\mathrm{S}$ is number of naturalized plant taxa in the survey area, $\mathrm{N} \cdot \mathrm{V}$ is total number of vascular plant taxa in the survey area)

Urbanization index $=\mathrm{S} / \mathrm{N} \times 100$

( $\mathrm{S}$ is number of naturalized plant taxa in the survey area, $\mathrm{N}$ is total number of naturalized plant taxa in the country)

\section{Results and Discussion}

\section{Species composition}

Based on voucher specimens collected in Oeumsan Mountain area, vascular plants of this region were identified to be 509 taxa (436 species 4 subspecies 57 varieties 12 forms) that belong to 98 families, 301 genera (Table 2, Appendix 1), which corresponded to $12.5 \%$ of 4,071 vascular plant taxa of South Korea (Lee, 1996a), 28.3\% of 1,796 vascular plant taxa in Gangwon-do (Gangwon-do, 2010) as well as $54.1 \%$ and $59.1 \%$ of 940 and 861 vascular plant taxa in Hongcheon-gun and Hoengseong-gun, respectively (Gangwon-do, 2010). Thus, species diversity in this region was found to be relatively high. On the other hand, these results were significantly different from 259 and 133 taxa in these regions reported by Lee and Jeon (2002) and Eom et al. (2009), respectively, which seemed to be due to the in-depth surveys conducted for this study through various routes over the course of 2 years.

Wild plants with the highest proportion of occurrence in
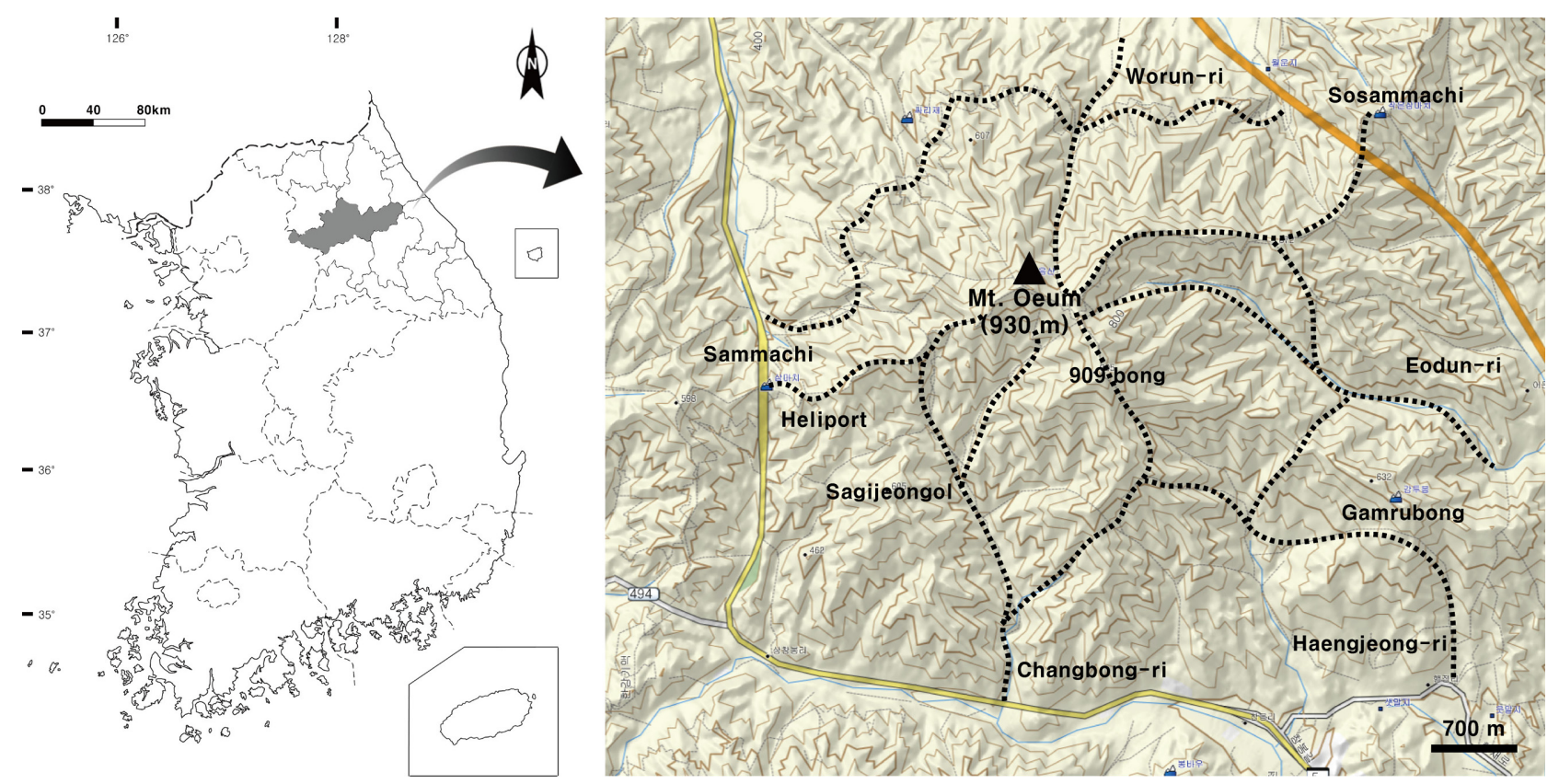

Fig. 1. Map of investigated area (left) and route (right). 
Table 1. Investigation dates and routes of survey area.

\begin{aligned} & \hline \multicolumn{1}{c}{ Date } \multicolumn{1}{c}{ Routes of investigation } \\ & \hline 25 Mar 2016 Eodun-ri $\rightarrow$ Forest road $\rightarrow$ Summit $\rightarrow$ Forest road $\rightarrow$ Eodun-ri \\ & 8 Apr 2016 Sammachi $\rightarrow$ Heliport $\rightarrow$ Geobukbawi $\rightarrow$ Summit $\rightarrow$ 909 bong $\rightarrow$ Changbong-ri \\ & 29 Apr 2016 Sammachi $\rightarrow$ Heliport $\rightarrow$ Geobukbawi $\rightarrow$ Summit $\rightarrow$ Geobukbawi $\rightarrow$ Sammachi \\ & 20 May 2016 Sammachi $\rightarrow$ Heliport $\rightarrow$ Geobukbawi $\rightarrow$ Summit $\rightarrow$ Geobukgawi $\rightarrow$ Sammachi \\ & 17 Jun 2016 Sosammachi $\rightarrow$ Forest road $\rightarrow$ Summit $\rightarrow$ S09 bong $\rightarrow$ Changbong-ri \\ & 15 Jul 2016 Changbong-ri $\rightarrow$ Sagijeongol $\rightarrow$ Summit $\rightarrow$ Geobukbawi $\rightarrow$ Heliport $\rightarrow$ Sammachi \\ & 29 Jul 2016 Worun-ri $\rightarrow$ Forest road $\rightarrow$ Summit $\rightarrow$ Geobukbawi $\rightarrow$ Sagijeongol $\rightarrow$ Changbong-ri \\ & 12 Aug 2016 Sammachi $\rightarrow$ Heliport $\rightarrow$ Geobukbawi $\rightarrow$ Summit $\rightarrow$ 909bong $\rightarrow$ Gamrubong $\rightarrow$ Haengjeong-ri \\ & 29 Aug 2016 Sammachi $\rightarrow$ Heliport $\rightarrow$ Geobukbawi $\rightarrow$ Summit $\rightarrow$ Sagijeongol $\rightarrow$ Changbong-ri \\ & 10 Sep 2016 Changbong-ri $\rightarrow$ S09 bong $\rightarrow$ Summit $\rightarrow$ Forest road $\rightarrow$ Worun-ri \\ & 30 Sep 2016 Sammachi $\rightarrow$ Heliport $\rightarrow$ Geobukbawi $\rightarrow$ Summit $\rightarrow$ Forest road $\rightarrow$ Sosammachi \\ & 7 Oct 2016 Worun-ri $\rightarrow$ Forest road $\rightarrow$ Summit $\rightarrow$ Geobukbawi $\rightarrow$ Sagijeongol $\rightarrow$ Changbong-ri \\ & 28 Oct 2016 Sammachi $\rightarrow$ Heliport $\rightarrow$ Geobukbawi $\rightarrow$ Summit $\rightarrow$ S09 bong $\rightarrow$ Gamrubong $\rightarrow$ Haengjeong-ri \\ & 13 May 2017 Eodun-ri $\rightarrow$ Forest road $\rightarrow$ Summit $\rightarrow$ Sammachi \\ & 18 Jun 2017 Changbong-ri $\rightarrow$ S09 bong $\rightarrow$ Summit $\rightarrow$ Forest road $\rightarrow$ Worun-ri \\ & 22 Jul 2017 Sosammachi $\rightarrow$ Forest road $\rightarrow$ Summit $\rightarrow$ S09 bong $\rightarrow$ Changbong-ri \\ & 2 Sep 2017 Sammachi $\rightarrow$ Heliport $\rightarrow$ Geobukbawi $\rightarrow$ Summit $\rightarrow$ Sagijeongol $\rightarrow$ Changbong-ri \\ & \hline\end{aligned}

Table 2. The abridged list of the plants in Oeumsan Mountatin.

\begin{tabular}{lccccccc}
\hline \hline \multicolumn{1}{c}{ Taxa } & Fam. & Gen. & Sp. & Subsp. & Var. & F. & Total \\
\hline Pteridophyta & 9 & 15 & 24 & - & 4 & - & 28 \\
Gymnospermae & 3 & 4 & 4 & - & - & - & 4 \\
Angiospermae & 86 & 282 & 408 & 4 & 53 & 12 & 477 \\
Dicotyledons & 74 & 228 & 323 & 4 & 42 & 9 & 378 \\
Monocotyledons & 12 & 54 & 85 & - & 11 & 3 & 99 \\
$\quad$ Total & 98 & 301 & 436 & 4 & 57 & 12 & 509 \\
\hline
\end{tabular}

Oeumsan Mountain were Compositae, including 52 taxa, followed by Gramineae with 39 taxa, Rosaceae with 27 taxa, Leguminosae with 25 taxa, both Ranunculaceae and Polygonaceae with 21 taxa, and Liliaceae with 20 taxa.

Among the vegetation of the Oeumsan Mountain forests, Quercus mongolica, Quercus variabilis, and Acer pictum subsp. mono were dominant, and climbing plants such as Rubus coreanus, Rubus oldhamii, and Tripterygium regelii were distributed in areas with a poor upper canopy. Previous studies also reported that Oeumsan Mountain had plant species mostly belonging to the family Fagaceae (Lee and Jeon, 2002), and Rubus coreanus, Actinidia polygama, Tripterygium regelii, and Actinidia arguta were also commonly found (Eom et al., 2009), which were similar to the results of our study.

Since Oeumsan Mountain is relatively perilous and steep, it seems that general climbers tended not to frequently visit this mountain. However, there are forest roads and military roads at the top of the southern slope, leading to military bases, and Jungang Expressway and a national highway are adjacent to the east and west from the peak, respectively. It is predicted that these would gradually increase indirect disturbance. Moreover, there were some shooting ranges, transmitting towers, heliports, and training fields inside and around the forests due to regional characteristics, and there were also military training facilities and human trampling in some areas, which have resulted in devegetation of herbaceous species. In addition, there were forest roads to military bases that were expanded at the top of the area, leaving cut slopes, where vegetation was poorly established. This led to collapses of soils and rocks, resulting in damage to vegetation of neighboring 
forests. Therefore, these regions need to be multilaterally managed considering, regional characteristics, in order to conserve the plant resource of the region.

\section{Endemic plants}

In the 509 taxa identified from the survey area, there were 9 taxa of endemic plants that belong to a total of 7 families 9 genera including Populus tomentiglandulosa, Salix koriyanagi, Aconitum pseudolaeve, Clematis trichotoma, Asarum versicolor, Corydalis lineariloba, Eleutherococcus divaricatus var. chiisanensis, Sillaphyton podagraria, and Abeliophyllum distichum (Table 3), which corresponded to $2.5 \%$ of 360 taxa of endemic plants in South Korea (Chung et al., 2017). Of these, Populus tomentiglandulosa and Salix koriyanagi were found at low altitude areas near the beginnings of hiking trails, and Aconitum pseudolaeve, Clematis trichotoma, Eleutherococcus divaricatus var. chiisanensis, and Sillaphyton podagraria often were distributed in mid-forest areas inside forests and slopes of forest roads. Asarum versicolor and Corydalis lineariloba were found to inhabit around valleys in low-lying lands. On the other hand, Abeliophyllum distichum, known to inhabit in
Gyeonggi-do, Chungcheongbuk-do, Gyeongsangbuk-do, and Jeollabuk-do (Chung et al., 2010; Shin et al., 2010; Lee et al. 2014) has been reported to maintain its population mostly through vegetative propagation (Kang et al., 2000; Kim and Kim, 2004; Shin et al., 2010), due to a low germination rate and no simultaneity in germination (Yoo and Kim, 1993). In addition, this species is known to inhabit in areas with relatively poor growing conditions, such as between the rocks, around farmlands, or boulder zones along mountain streams (Lee, 1976). The Abeliophyllum distichum plants found in Oeumsan Mountain during this study were the first documented case in Gangwon-do. Four individual plants were found between the rocks in a mountain stream at Sammachi-ri of Hongcheon-gun. According to an inquiry survey, a small number of plants of this species were introduced around buildings in a Buddhist temple nearby in the past, but there has been no artificial planting nearby the stream. To reveal the origin of Abeliophyllum distichum in Oeumsan Mountain, further investigation is needed to determine whether this species was originally planted as ornamentals at the Buddhist temple and then naturalized in the corresponding area resulting from rain spells and typhoons, or

Table 3. List of endemic plants in Oeumsan Mountain.

\begin{tabular}{ll}
\hline \hline \multicolumn{1}{c}{ Family name/Korean name } & \multicolumn{1}{c}{ Scientific name/Korean name } \\
\hline Salicaceae 버드나무과 & Populus tomentiglandulosa T. B. Lee 은사시나무(cult.) \\
& Salix koriyanagi Kimura 키버들 \\
Ranunculaceae 미나리아재비과 & Aconitum pseudolaeve Nakai 진범 \\
& Clematis trichotoma Nakai 할미밀망 \\
Aristolochiaceae 쥐방울덩굴과 & Asarum versicolor (K.Yamaki) Y. N. Lee 무늬족도리풀 \\
Fumariaceae 현호색과 & Corydalis lineariloba Siebold \& Zucc. 선현호색 \\
Araliaceae 두릅나무과 & Eleutherococcus divaricatus var. chiisanensis (Nakai) C. H. Kim \& B. Y. Sun 지리산오갈피 \\
Umbelliferae 산형과 & Sillaphyton podagraria (H.Boissieu) Pimenov 덕우기름나물 \\
Oleaceae 물푸레나무과 & Abeliophyllum distichum Nakai 미선나무 \\
\hline
\end{tabular}

Table 4. List of endangered wild and rare plants in Oeumsan Mountain.

\begin{tabular}{llc}
\hline \hline \multicolumn{1}{c}{ Family name } & \multicolumn{1}{c}{ Scientific name/Korean name } & Grade \\
\hline Oleaceae 물푸레나무과 & Abeliophyllum distichum Nakai 미선나무 & 2, CR \\
Ranunculaceae 미나리아재비과 & Eranthis stellata Maxim. 너도바람꽃 & LC \\
Aristolochiaceae 쥐방울덩굴과 & Aristolochia contorta Bunge 쥐방울덩굴 & LC \\
Saxifragaceae 범의귀과 & Rodgersia podophylla A.Gray 도깨비부채 & LC \\
Violaceae 제비꽃과 & Viola albida Palib. 태백제비꽃 & LC \\
Solanaceae 가지과 & Viola diamantiaca Nakai 금강제비꽃 & LC \\
Araliaceae 두릅나무과 & Scopolia japonica Maxim. 미치광이풀 & LC \\
\hline 2, & Eleutherococcus divaricatus var. chiisanensis (Nakai) C. H. Kim \& B. Y. Sun 지리산오갈피 & DD \\
\hline
\end{tabular}

2, endangered wild plants 2 grade; CR, critically endangered; LC, least concerned; DD, data deficient. 
this region is the natural northern limit of this species. If this is found to be a natural population, it should be studied for genetic diversity and biogeographic characteristics, targeting the entire population of this species in South Korea.

\section{Endangered and rare plants}

Abeliophyllum distichum was the only endangered plant species found in the survey area, which was designated as a Grade 2 endangered species by the Ministry of Environment. There were 8 taxa of rare plants that belonged to 7 families and 7 genera, which accounted for $1.4 \%$ of the total 577 taxa of rare plants in South Korea (Korean National Arboretum, $2008 \mathrm{~b}$ ), as well as $20.0 \%$ and $32.0 \%$ of 40 and 25 taxa of rare plants in Hongcheon-gun and Hoengseong-gun, respectively (Gangwon-do, 2010). When classified according to the grades of rare plants, critically endangered species were Abeliophyllum distichum; least concerned species were Eranthis stellata, Aristolochia contorta, Rodgersia podophylla, Viola albida, Viola diamantiaca; and data deficient species was Eleutherococcus divaricatus var. chiisanensis (Table 4).

Of the identified taxa, Aristolochia contorta and Eleutherococcus divaricatus var. chiisanensis were found around beginnings of hiking trails, and Abeliophyllum distichum was detected in boulder areas of a mountain stream. In addition, Eranthis stellata, Rodgersia podophylla, and Scopolia japonica inhabited areas with various sizes of rocks in a valley within a forest, and Viola albida and Viola diamantiaca were on the slope to the mountaintops and ridge areas.

\section{Floristic regional indicator plants}

The floristic regional indicator plants specially designated by the Ministry of the Environment are useful taxa representing areas with similar environments, which are subdivided into 5 grades according to the area they inhabit (Ministry of Environment and National Institute of Environmental Research, 2014). Of the 509 taxa identified, 57 taxa were floristic regional indicator plants, which accounted for 4.5\% of the entire 1,255 indicator plant taxa (Ministry of Environment and National Institute of Environmental Research, 2014). This result was significantly different from 19 and 9 taxa reported by Lee and Jeon (2002) and Eom et al., (2009), respectively.

Classifications of these floristic regional indicator plants are as follows: Abeliophyllum distichum for Grade V, habitats are discontinuous and isolated with the narrowest area of distribution; Anemone reflexa, Chrysosplenium ramosum, Rodgersia podophylla, and Wisteria floribunda for Grade IV, northern or southern plants usually found in one subdistrict: 9
Table 5. List of floristic regional indicator plants in Oeumsan Mountain.

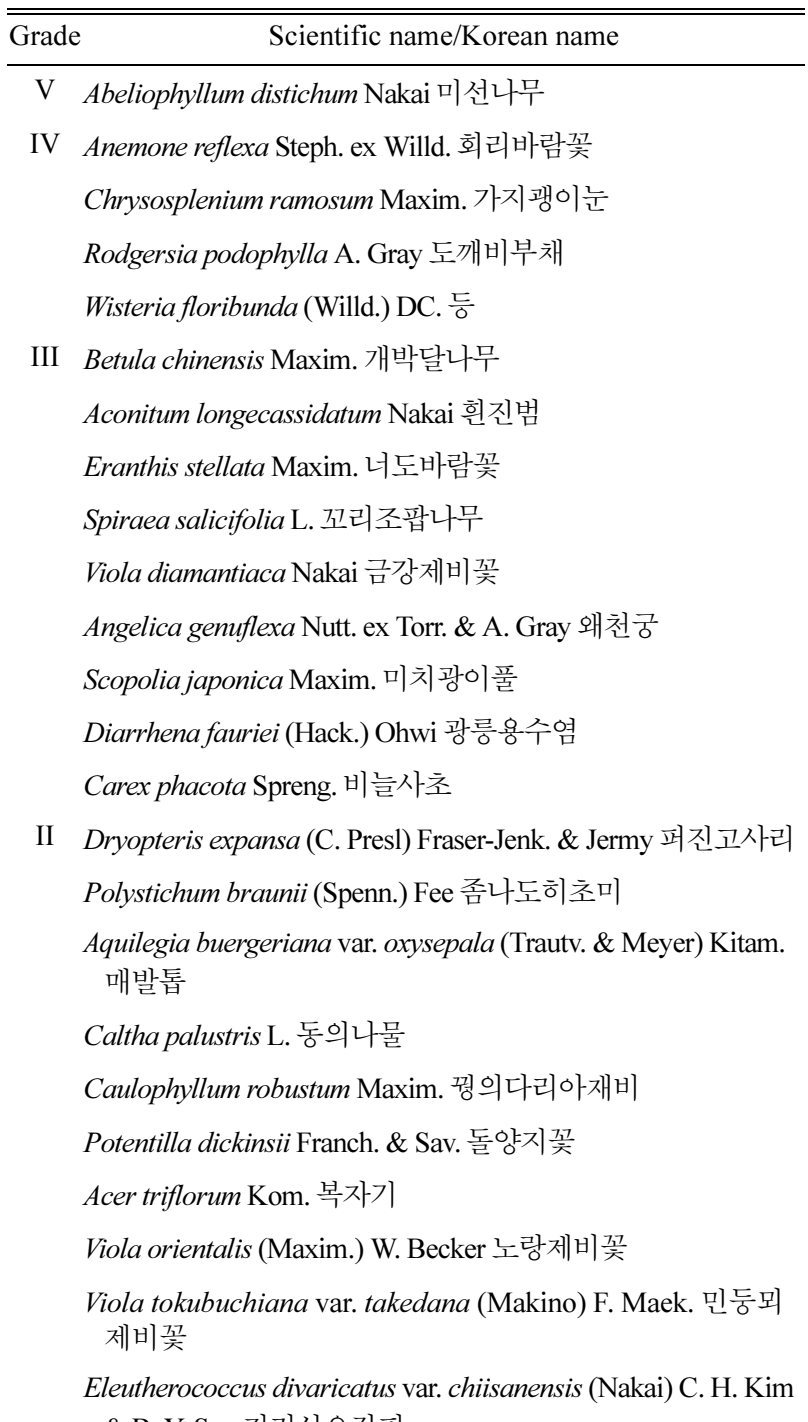
\& B. Y. Sun 지리산오갈피

Vaccinium hirtum var. koreanum (Nakai) Kitam. 산앵도나무

Primula jesoana Miq. 큰앵초

Galium paradoxum Maxim. 두메갈퀴

Brachybotrys paridiformis Maxim. ex Oliv. 당개지치

Weigela florida (Bunge) A. DC. 붉은병꽃나무

Adoxa moschatellina $\mathrm{L}$. 연복초

Cirsium setidens (Dunn) Nakai 고려엉겅퀴

Ligularia fischeri (Ledeb.) Turcz. 곰취

Heloniopsis koreana Fuse \& N. S. Lee \& M. N. Tamura 처녀 치마

I Dryopteris crassirhizoma Nakai 관중

Matteuccia struthiopteris (L.) Tod. 청나래고사리

Polystichum ovatopaleaceum var. coraiense (H.Christ) Sa.Kurata 참나도히초미 
Table 5. Continued.

\begin{tabular}{l}
\hline \hline Grade \\
\hline I $\quad$ Suglans mandshurica Maxim. 가래나무 \\
Lychnis cognata Maxim. 동자꽃 \\
Aconitum jaluense Kom. 투구꽃 \\
Anemone raddeana Regel 뀡의바람꽃 \\
Chloranthus japonicus Siebold 홀아비꽃대 \\
Aristolochia contorta Bunge 쥐방울덩굴 \\
Hylomecon ernalis Maxim. 피나물 \\
Hylotelephium verticillatum (L.) H. Ohba 세잎뀡의비름 \\
Chrysosplenium japonicum (Maxim.) Makino 산괭이눈 \\
Ribes mandshuricum (Maxim.) Kom. 까치밥나무 \\
Malus baccata (L.) Borkh. 야광나무 \\
Potentilla cryptotaeniae Maxim. 물양지꽃 \\
Vicia psendo-orobus Fisch. \& C. A. Mey. 큰등갈퀴 \\
Oxalis obtriangulata Maxim. 큰괭이밥 \\
Impatiens nolitangere L. 노랑물봉선 \\
Buxus koreana Nakai ex Chung \& al. 회양목 \\
Clinopodium micranthum (Regel) Hara 두메층층이 \\
Lonicera praeflorens Batalin 올괴불나무 \\
Cirsium pendulum Fisch. ex DC. 큰엉겅퀴 \\
Sagittaria aginashi Makino 보풀 \\
Carex maackii Maxim. 타래사초 \\
\hline
\end{tabular}

taxa including Betula chinensis, Aconitum longecassidatum, Eranthis stellata, Spiraea salicifolia, and Viola diamantiaca for Grade III that inhabit in 2 subdistricts; 19 taxa including Dryopteris expansa, Polystichum braunii, Aquilegia buergeriana var. oxysepala, Caltha palustris, and Caulophyllum robustum were Grade II that are distributed nationwide, but mostly found in areas $>1,000 \mathrm{~m}$ in elevation; 24 taxa including Dryopteris crassirhizoma, Matteuccia struthiopteris, Anemone raddeana, Impatiens nolitangere, and Lonicera praeflorens for Grade I that are distributed in 3 subdistricts (Table 5).

\section{Naturalized plants}

Naturalized plants refer to plant species that are not native, but have been introduced to the country via artificial or natural ways, and propagate and reproduce in nature on their own (Koh et al., 1995). A total of 35 naturalized plant taxa that belong to 13 families 32 genera were identified in this study (Table 6) including ecosystem disturbing plants, such as Rumex acetosella, Ambrosia artemisiifolia, and Aster pilosus, and their naturalized ratio and urbanization index were calculated to be $6.9 \%$ and $10.9 \%$, respectively. Considering the naturalized ratio of Korean forest areas is $14.0 \%$ (Oh et al., 2009), it seems that the vegetation of this area has been conserved relatively well. The naturalized plants were found mostly around private residences in lowlying lands and military facilities where vehicles frequently pass by during military movements and transportation of

Table 6. List of naturalized plants in Oeumsan Mountain.

\begin{tabular}{ll}
\hline \hline Family name/Korean name & \multicolumn{1}{c}{ Scientific name/Korean name } \\
\hline Polygonaceae 마디풀과 & Fallopia dentatoalata (F. Schmidt) Holub 큰닭의덩굴 \\
& Fallopia dumetorum (L.) Holub 닭의덩굴 \\
& Persicaria orientalis (L.) Spach 털여뀌 \\
& Rumex acetosella L. 애기수영 \\
Phytolaccaceae 자리공과 & Phytolacca americana L. 미국자리공 \\
Caryophyllaceae 석죽과 & Silene armeria L. 끈끈이대나물 \\
Amaranthaceae 비름과 & Amaranthus lividus L. 개비름 \\
Cruciferae 십자화과 & Amaranthus patulus Bertol. 가는털비름 \\
& Brassica juncea (L.) Czern. 갓(cult.) \\
Leguminosae 콩과 & Lepidium virginicum L. 콩다닥냉이 \\
& Amorpha fruticosa L. 족제비싸리(cult.) \\
& Melilotus alba Medicus ex Desv. 흰전동싸리 \\
& Robinia pseudoacacia L. 아까시나무(cult.) \\
& Trifolium repens L. 토끼풀 \\
Euphorbiaceae 대극과 & Euphorbia supina Raf. 애기땅빈대
\end{tabular}


Table 6. List of naturalized plants in Oeumsan Mountain.

\begin{tabular}{|c|c|}
\hline Family name/Korean name & Scientific name/Korean name \\
\hline Simaroubaceae 소태나무과 & Ailanthus altissima (Mill.) Swingle 가죽나무(cult.) \\
\hline Onagraceae 바늘꽃과 & Oenothera biennis L. 달맞이꽃 \\
\hline Solanaceae 가지과 & Solanum americanum Mill. 미국까마중 \\
\hline Scrophulariaceae 현삼과 & Veronica arvensis L. 선개불알풀 \\
\hline \multirow[t]{11}{*}{ Compositae 국화과 } & Ambrosia artemisiifolia L. 돼지풀 \\
\hline & Aster pilosus Willd. 미국쑥부쟁이 \\
\hline & Bidens frondosa L. 미국가막사리 \\
\hline & Carduus crispus L. 지느러미엉겅퀴 \\
\hline & Conyza canadensis (L.) Cronquist 망초 \\
\hline & Cosmos bipinnatus Cav. 코스모스 \\
\hline & Erigeron annuus (L.) Pers. 개망초 \\
\hline & Erigeron strigosus Muhl. 주걱개망초 \\
\hline & Galinsoga ciliata (Raf.) S. F. Blake 털별꽃아재비 \\
\hline & Rudbeckia bicolor Nutt. 원추천인국 \\
\hline & Taraxacum officinale Weber 서양민들레 \\
\hline \multirow[t]{5}{*}{ Gramineae 벼과 } & Dactylis glomerata L. 오리새 \\
\hline & Festuca arundinacea Schreb. 큰김의털 \\
\hline & Lolium perenne L. 호밀풀 \\
\hline & Panicum dichotomiflorum Michx. 미국개기장 \\
\hline & Phleum pratense L. 큰조아재비 \\
\hline
\end{tabular}

military supplies. Amorpha fruticosa, Robinia pseudoacacia and Ailanthus altissima inhabited slopes of forest roads where vegetation of herbaceous species was poorly established, and Lepidium virginicum, Trifolium repens, and Erigeron annuus occupied relatively large areas in the open fields such as farmlands, pastures, and heliports.

Rumex acetosella, Ambrosia artemisiifolia, and Aster pilosus have been controlled because they are ecosystem disturbing plants that are harmful to humans. Nevertheless, only a small number of them were found in dry fallow lands located at the edge of relatively desolate forests in low-lying lands, so that they were not considered to have significant effects on the plant ecosystem.

\section{Conflict of Interest}

Authors declare that there is no conflict of interest.

\section{Acknowledgments}

This study was supported by 2016 Research Grant from Kangwon National University (No. 520160274).

\section{Literature Cited}

Chung, G. Y., K. S. Chang, J.-M. Chung, H. J. Choi, W.-K. Paik and J.-O. Hyun. 2017. A checklist of endemic plants on the Korean Peninsula. Korean Journal of Plant Taxonomy 47: 264-288. (in Korean)

Chung, G. Y., M. S. Park, B. M. Nam., K. N. Hong, J. Jang, H. J. Jeong and K. O. Yoo. 2010. Distribution of vascular plants in Gallasan (Andong-si, Uiseong-gun, Gyeongbuk). Korean Journal of Plant Resources 23: 99-114. (in Korean)

Eom, H. J., K. S. Chang and C. S. Chang. 2009. Flora of Hongcheon area of Gangwon-do. Bulletin of the Arboretum Seoul National University 27: 29-60. (in Korean)

Gangwon-do. 2010. Inhabitation and Distribution of Wild Animal and Plant in Gangwon-do. Gangwon-do, 215 pp. (in Korean)

Hongcheon-gun. 2014. Retrieved Dec 5, 2017, available from https:// www.hongcheon.gangwon.kr.

Hoengseong-gun. 2015. Retrieved Dec 5, 2017, available from http:// www.hsg.go.kr.

Kang, U., C.-S. Chang and Y. S. Kim. 2000. Genetic structure and conservation considerations of rare endemic Abeliophyllum distichum Nakai (Oleaceae) in Korea. Journal of Plant Research 113: 127- 
138.

Kim, D.-K. and J.-H. Kim. 2004. Numerical taxonomy of tribe Forsythieae (Oleaceae) in Korea. Korean Journal of Plant Taxonomy 34: 189-203. (in Korean)

Koh, K. S., I. G. Kang, M. H. Suh, J. H. Kim, K. D. Kim, J. H. Kil, H. I. Rhu, D. S. Kong, E. B. Lee and E. S. Chun. 1995. Survey for Ecological Impact by Naturalized Organism (I). National Institute of Environmental Research, Incheon, 74 pp. (in Korean)

Korea Meterological Adminstration. 2015. Retrieved Dec 15, 2017, available from https://data.kma.go.kr.

Korea National Arboretum. 2008a. Illustrated Pteridophytes of Korea. Korea National Arboretum, Pocheon, 547 pp. (in Korean)

Korea National Arboretum. 2008b. Rare Plants Data Book in Korea. Korea National Arboretum, Pocheon, 332 pp. (in Korean)

Korea National Arboretum and The Korean Society of Plant Taxonomists. 2007. A Synonymic List of Vascular Plant in Korea. Korea National Arboretum, Pocheon, 534 pp. (in Korean)

Lee, C.-S. and K.-H. Lee. 2015. Pteridophytes of Korea: Lycophytes \& Ferns. Geobook, Seoul, 471 pp. (in Korean)

Lee, H.-Y., T.-G. Kim and C.-H. Oh. 2014. Recently augmented natural habitat of Abeliopyllum distichum Nakai in Yeoju-si, Gyunggido, Korea. Korean Journal of Environment and Ecology 28: 6270. (in Korean)

Lee, T. B. 1976. New forms of Abeliophyllum distichum. Korean Journal of Plant Taxonomy 7: 21-22. (in Korean)

Lee, T. B. 2003a. Coloured Flora of Korea. Vol. I. Hyangmunsa, Seoul, 914 pp. (in Korean)

Lee, T. B. 2003b. Coloured Flora of Korea. Vol. II. Hyangmunsa, Seoul, 910 pp. (in Korean)

Lee, W. B and Y. M. Jeon. 2002. Flora of Mt. Oeum (HoengseongHongcheon) and Adjacent Areas. 2nd Natural Environment Survey. Ministry of Environment, Gwacheon. Pp. 46-71. (in Korean) Lee, W. T. 1996a. Coloured Standard Illustrations of Korean Plants.
Academy Publishing Co., Seoul, 624 pp. (in Korean)

Lee, W. T. 1996b. Lineamenta Florae Koreae. Academy Publishing Co., Seoul, 1688 pp. (in Korean)

Lee, Y.-M., S.-H. Park, S.-Y. Jung, S.-H. Oh and J.-C. Yang. 2011. Study on the current status of naturalized plants in South Korea. Korean Journal of Plant Taxonomy 41: 87-101. (in Korean)

Lee, Y. N. 2006a. New flora of Korea (I). Kyo-Hak Publishing Co., Seoul, 975 pp. (in Korean)

Lee, Y. N. 2006b. New flora of Korea (II). Kyo-Hak Publishing Co., Seoul, 888 pp. (in Korean)

Ministry of Environment and National Institute of Environmental Research. 2014. Forth Round of the National Natural Environmental Research Guidelines. Ministry of Environment and National Institute of Environmental Research, Gwacheon and Incheon. Pp. 173-226. (in Korean)

Ministry of Environment. 2012. Retrieved Dec. 5, 2017, available from http://www.me.go.kr.

Numata, M. 1975. Naturalized Plants. Dai Nippon Printing Co., Tokyo, 160 pp. (in Japanese)

Oh, C. H., Y. H. Kim, H. Y. Lee and S. H. Ban. 2009. The naturalization index of plant around abandoned military camps in civilian control zone. Journal of Korean Environment Research Technology 12: 59-76. (in Korean)

Shin, H.-T., M.-H. Yi, Y.-S. Kim, B.-C. Lee and J.-W. Yoon. 2010. Recently augmented natural habitats of Forsythia koreana (Rehder) Nakai and Abeliophyllum distichum Nakai in Korea. Korean Journal of Plant Taxonomy 40: 274-277. (in Korean)

Yim, Y. J. and E. S. Jeon. 1980. Distribution of naturalized plants in the Korean peninsula. Journal of Plant Biology 23: 69-83. (in Korean)

Yoo, Y. K. and K. S. Kim. 1993. Studies on the seed propagation of white Forsythia (Abeliophyllum distichum Nakai) 1. Physiology and condition of germination. Horticultural Science and Technology 10: 98-99. (in Korean)

\title{
오음산(강원, 홍천 및 횡성)의 관속식물상
}

\author{
김경아 · 천경식 ${ }^{1}$ 유기억* \\ 강원대학교 생명과학과, ${ }^{1}$ 상지대학교 생명과학과
}

적 요: 강원도 홍천군 및 횡성군에 위치한 오음산 $(930 \mathrm{~m})$ 에 대한 관속식물 조사를 2016년 3월부터 2017년 9 월까지 수행하였다. 조사 결과 분포가 확인된 관속식물은 98 과 301속 436종 4아종 57변종 12 품종으로 총 509 분류군이었다. 특산식물은 9 분류군이었으며, 멸종위기야생식물은 2 급에 1 분류군이었고, 희귀식물은 8 분 류군이었다. 식물구계학적 특정식물로는 V등급 1 분류군, IV등급 4 분류군, III등급 9분류군, II등급 19 분류군, I등급 24 분류군으로 총 57 분류군이 조사되었다. 귀화식물은 생태계교란야생식물 2 분류군을 포함하여 총 35 분류군이 확인되었으며, 도시화지수와 귀화율은 각각 $6.9 \%$ 와 $10.9 \%$ 로 산출되었다.

주요어: 관속식물, 특산, 멸종위기식물, 희귀식물, 귀화식물 
Appendix 1. List of vascular plants of Oeumsan Mountain.

Scientific name/Korean name/Voucher number

Equisetaceae속새과

Equisetum arvense L. 쇠뜨기 KWNU91173

Osmundaceae 고비과

Osmunda cinnamomea (L.) C. Presl 뀡고비 WNU90636

Osmunda japonica Thunb. 고비 KWNU90635

Dennstaedtiaceae 잔고사리과

Dennstaedtia hirsuta (Sw.) Mett. ex Miq. 잔고사리 KWNU91327

Dennstaedtia wilfordii (T. Moore) Christ 황고사리 KWNU91110

Pteridium aquilinum var. latiusculum (Desv.) Underw. ex A. Heller 고사리 KWNU90505

Aspleniaceae 꼬리고사리과

Asplenium incisum Thunb. 꼬리고사리 KWNU91236

Asplenium ruprechtii Sa. Kurata 거미고사리 KWNU92689

Thelypteridaceae 처녀고사리과

Thelypteris palustris (Salisb.) Schott 처녀고사리 KWNU90677

Woodsiaceae 우드풀과

Woodsia manchuriensis Hook. 만주우드풀 KWNU90503

Woodsia polystichoides D. C. Eaton 우드풀 KWNU90632

Onocleaceae 야산고비과

Matteuccia struthiopteris (L.) Tod. 청나래고사리 KWNU91644

Onoclea sensibilis var. interrupta Maxim. 야산고비 KWNU91641

Pentarhizidium orientalis (Hook.) Hayata 개면마 KWNU91642

Athyriaceae 개고사리과

Athyrium brevifrons Nakai ex Kitagawa 참새발고사리 KWNU91246

Athyrium niponicum (Mett.) Hance 개고사리 KWNU90679

Athyrium yokoscense (Franch. \& Sav.) Christ 뱀고사리

KWNU90509

Cornopteris crenulatoserrulata (Makino) Nakai 응달고사리 KWNU91233

Deparia japonica (Thunb.) M. Kato 진고사리 KWNU91627

Deparia orientalis var. albosquamata M. Kato 흰털고사리 KWNU91322

Dryopteridaceae 관중과

Dryopteris bissetiana (Baker) C. Chr. 산족제비고사리 KWNU91225

Dryopteris chinensis (Baker) Koidz. 가는잎족제비고사리 KWNU91223

Dryopteris crassirhizoma Nakai 관중 KWNU91239

Dryopteris expansa (Pr.) Franch.-Jenkins et Jermy 퍼진고사리 KWNU92727

Dryopteris monticola (Makino) C. Chr. 왕지네고사리 KWNU91636

Polystichum braunii (Spenn.) Fee 좀나도히초미 KWNU92692
Appendix 1. Continued.

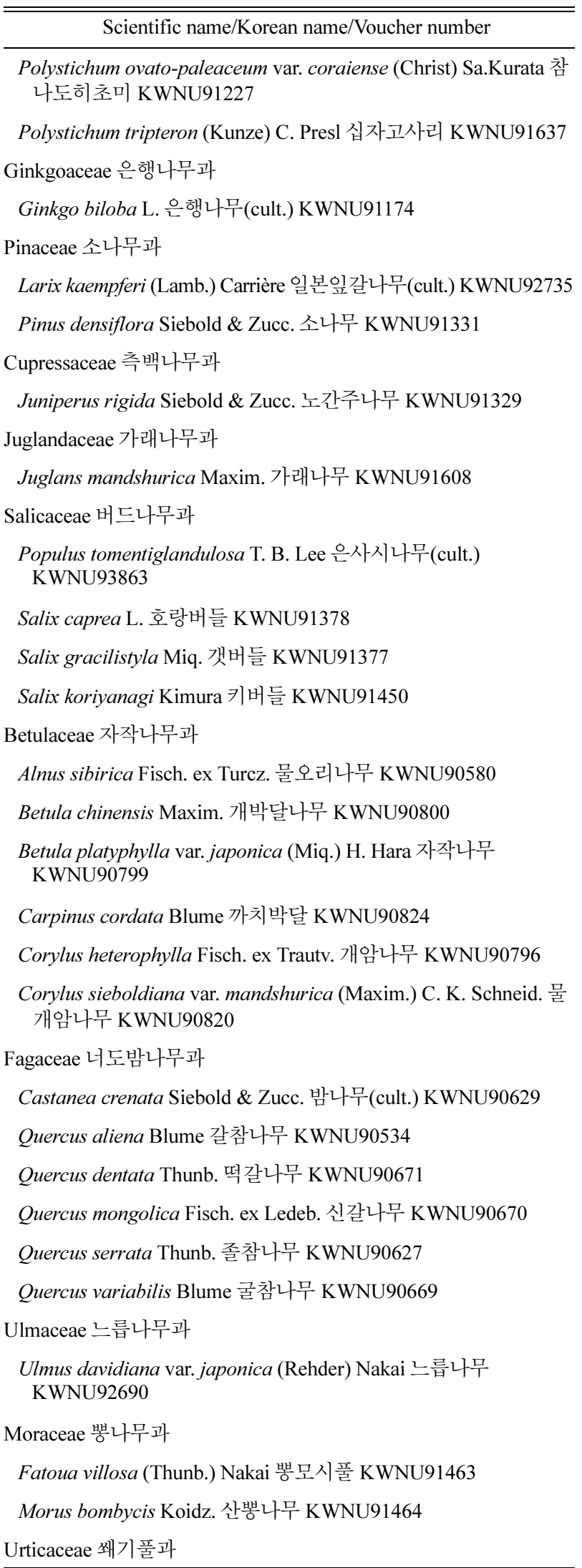


Appendix 1. Continued.

\begin{tabular}{|c|}
\hline Scientific name/Korean name/Voucher number \\
\hline Boehmeria longispica Steud. 왜모시풀 KWNU91401 \\
\hline Boehmeria platanifolia Franch. \& Sav. 개모시풀 KWNU91573 \\
\hline Boehmeria spicata (Thunb.) Thunb. 좀깨잎나무 KWNU91403 \\
\hline Pilea mongolica Wedd. 모시물통이 KWNU91571 \\
\hline Polygonaceae 마디풀과 \\
\hline Fallopia dumetorum (L.) Holub 닭의덩굴 KWNU90463 \\
\hline Fagopyrum esculentum Moench 메밀(cult.) KWNU91381 \\
\hline $\begin{array}{l}\text { Fallopia dentatoalata (F. Schmidt) Holub 큰닭의덩굴 } \\
\text { KWNU90917 }\end{array}$ \\
\hline Fallopia dumetorum (L.) Holub 닭의덩굴 KWNU90463 \\
\hline $\begin{array}{l}\text { Persicaria dissitiflora (Hemsl.) H. Gross ex Mori 가시여뀌 } \\
\text { KWNU90967 }\end{array}$ \\
\hline $\begin{array}{l}\text { Persicaria filiformis (Thunb.) Nakai ex Mori 이삭여 뀌 } \\
\text { KWNU90966 }\end{array}$ \\
\hline Persicaria hydropiper (L.) Spach 여뀌 KWNU90460 \\
\hline Persicaria lapathifolia (L.) Gray 흰여뀌 KWNU90697 \\
\hline Persicaria longiseta (Bruijn) Kitag. 개여뀌 KWNU90121 \\
\hline Persicaria nepalensis (Meisn.) H. Gross 산여뀌 KWNU90689 \\
\hline Persicaria orientalis (L.) Spach 털여뀌 KWNU92677 \\
\hline Persicaria perfoliata (L.) H. Gross 며느리배꼽 KWNU90970 \\
\hline $\begin{array}{l}\text { Persicaria posumbu var. laxiflora (Meisn.) H. Hara 장대여뀌 } \\
\text { KWNU90725 }\end{array}$ \\
\hline Persicaria sagittata (L.) H. Gross 미꾸리낚시 KWNU90722 \\
\hline $\begin{array}{l}\text { Persicaria senticosa (Meisn.) H. Gross ex Nakai 며느리밑씻개 } \\
\text { KWNU90719 }\end{array}$ \\
\hline $\begin{array}{l}\text { Persicaria thunbergii (Siebold \& Zucc.) H. Gross 고마리 } \\
\text { KWNU90716 }\end{array}$ \\
\hline $\begin{array}{l}\text { Persicaria viscofera var. robusta (Makino) Hiyama 큰근근이여뀌 } \\
\text { KWNU90976 }\end{array}$ \\
\hline Polygonum aviculare L. 마디풀 KWNU90467 \\
\hline Rumex acetosa L. 수영 KWNU90465 \\
\hline Rumex acetosella L. 애기수영 KWNU90969 \\
\hline Rumex japonicus Houtt. 참소리쟁이 KWNU90920 \\
\hline Phytolaccaceae 자리공과 \\
\hline Phytolacca americana L. 미국자리공 KWNU92769 \\
\hline Portulacaceae 쇠비름과 \\
\hline Portulaca oleracea L. 쇠비름 KWNU91369 \\
\hline Caryophyllaceae 석죽과 \\
\hline Arenaria serpyllifolia L. 벼룩이자리 KWNU91375 \\
\hline $\begin{array}{l}\text { Cerastium holosteoides var. hallaisanense (Nakai) Mizush. 점나도 } \\
\text { 나물 KWNU91104 }\end{array}$ \\
\hline Dianthus chinensis L. 패랭이꽃 KWNU91448 \\
\hline Lychnis cognata Maxim. 동자꽃 KWNU91099 \\
\hline
\end{tabular}

Appendix 1. Continued.

\begin{tabular}{|c|}
\hline Scientific name/Korean name/Voucher number \\
\hline Pseudostellaria davidii (Franch.) Pax 덩굴개별꽃 KWNU91447 \\
\hline Pseudostellaria heterophylla (Miq.) Pax 개별꽃 KWNU91373 \\
\hline Sagina japonica (Sw.) Ohwi 개미자리 KWNU92744 \\
\hline Silene armeria L. 끈끈이대나물 KWNU92732 \\
\hline Silene firma Siebold \& Zucc. 장구채 KWNU91099 \\
\hline Silene seoulensis Nakai 가는장구채 KWNU92699 \\
\hline Stellaria alsine var. undulata (Thunb.) Ohwi 벼룩나물 KWNU92764 \\
\hline Stellaria aquatica (L.) Scop. 쇠별꽃 KWNU91444 \\
\hline Stellaria media (L.) Vill. 별꽃 KWNU92420 \\
\hline Chenopodiaceae 명아주과 \\
\hline $\begin{array}{l}\text { Chenopodium album var. centrorubrum Makino 명아주 } \\
\text { KWNU91541 }\end{array}$ \\
\hline Amaranthaceae 비름과 \\
\hline Achyranthes japonica (Miq.) Nakai 쇠무릎 KWNU91108 \\
\hline Amaranthus lividus L. 개비름 KWNU92738 \\
\hline Amaranthus patulus Bertol. 가는털비름 KWNU91376 \\
\hline Schisandraceae 오미자과 \\
\hline Schisandra chinensis (Turcz.) Baill. 오미자 KWNU90872 \\
\hline Lauraceae 녹나무과 \\
\hline Lindera obtusiloba Blume 생강나무 KWNU90652 \\
\hline Ranunculaceae 미나리아재비과 \\
\hline Aconitum ciliare DC. 놋젓가락나물 KWNU92726 \\
\hline Aconitum jaluense Kom. 투구꽃 KWNU90637 \\
\hline Aconitum longecassidatum Nakai 흰진범 KWNU90602 \\
\hline Aconitum pseudolaeve Nakai 진범 KWNU90596 \\
\hline Actaea asiatica H. Hara 노루삼 KWNU92724 \\
\hline Anemone raddeana Regel 꿩의바람꽃 KWNU90812 \\
\hline Anemone reflexa Steph. ex Willd. 회리바람꽃 KWNU90593 \\
\hline $\begin{array}{l}\text { Aquilegia buergeriana var. oxysepala (Trautv. \& Meyer) Kitam. 매 } \\
\text { 발톱 KWNU90811 }\end{array}$ \\
\hline Caltha palustris L. 동의나물 KWNU90592 \\
\hline $\begin{array}{l}\text { Cimicifuga dahurica (Turcz. ex Fisch. \& C. A. Mey.) Maxim. 눈빛 } \\
\text { 승마 KWNU90809 }\end{array}$ \\
\hline Clematis apiifolia DC. 사위질빵 KWNU90573 \\
\hline Clematis fusca var. violacea Maxim. 종덩굴 KWNU90570 \\
\hline Clematis heracleifolia DC. 병조희풀 KWNU93406 \\
\hline $\begin{array}{l}\text { Clematis terniflora var. mandshurica (Rupr.) Ohwi 으아리 } \\
\text { KWNU90643 }\end{array}$ \\
\hline Clematis trichotoma Nakai 할미밀망 KWNU90786 \\
\hline Eranthis stellata Maxim. 너도바람꽃 KWNU90567 \\
\hline Hepatica asiatica Nakai 노루귀 KWNU93407 \\
\hline
\end{tabular}


Appendix 1. Continued.

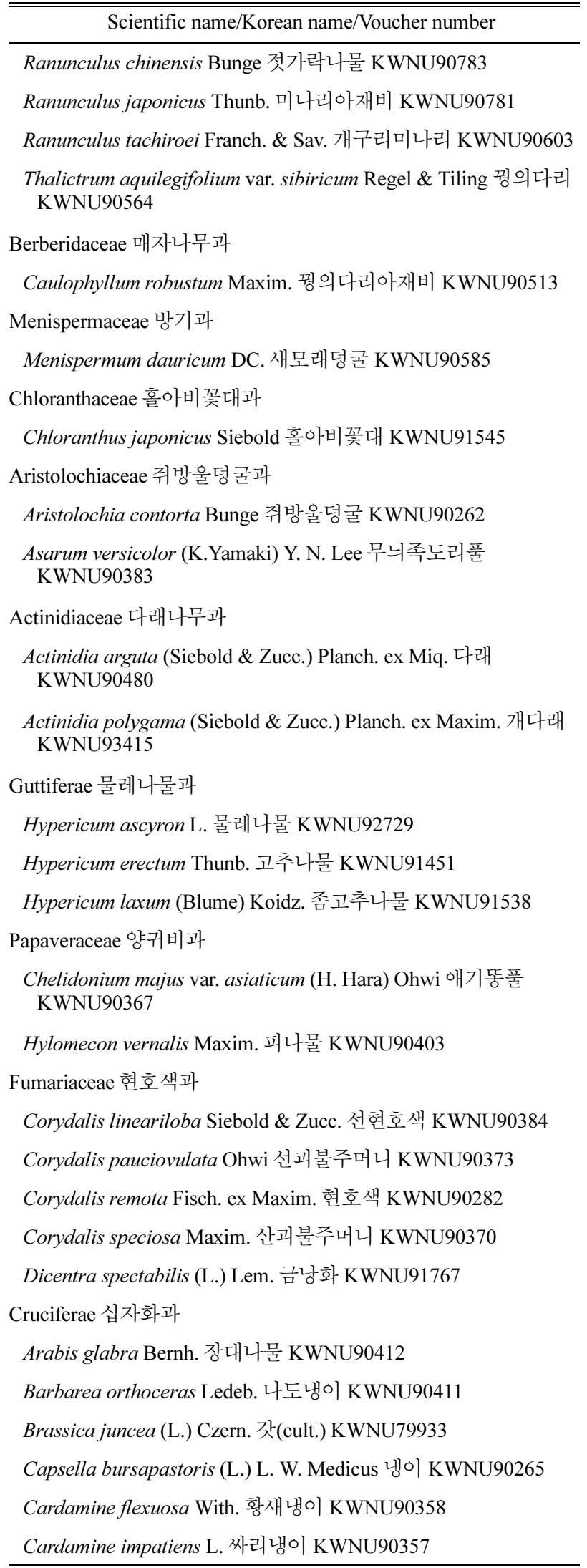

Appendix 1. Continued.

\begin{tabular}{l}
\hline \hline \multicolumn{1}{c}{ Scientific name/Korean name/Voucher number } \\
\hline Cardamine leucantha (Tausch) O. E. Schulz 미나리냉이 \\
KWNU90409 \\
Cardamine scutata Thunb. 큰황새냉이 KWNU92761 \\
Draba nemorosa L. 꽃다지 KWNU92693 \\
Lepidium virginicum L. 콩다닥냉이 KWNU90382 \\
Rorippa indica (L.) Hiern 개갓냉이 KWNU90043 \\
Rorippa palustris (Leyss.) Besser 속속이풀 KWNU90369 \\
Crassulaceae 돌나물과 \\
Hylotelephium verticillatum (L.) H. Ohba 세잎꿩의비름 \\
KWNU90986 \\
Sedum aizoon L. 가는기린초 KWNU90709 \\
Sedum kamtschaticum Fisch. \& Mey. 기린초 KWNU90731 \\
Sedum polytrichoides Hemsl. 바위채송화 KWNU90482 \\
Sedum sarmentosum Bunge 돌나물 KWNU90732 \\
Saxifragaceae 범의귀과 \\
Astilbe rubra Hook. f. \& Thomson 노루오줌 KWNU90441
\end{tabular}

Chrysosplenium flagelliferum F. Schmidt 애기괭이눈 KWNU90737

Chrysosplenium japonicum (Maxim.) Makino 산괭이눈 KWNU90486

Chrysosplenium ramosum Maxim. 가지괭이눈 KWNU90942

Deutzia glabrata Kom. 물참대 KWNU90487

Deutzia grandiflora var. baroniana Diels 바위말발도리 KWNU92747

Deutzia uniflora Shirai 매화말발도리 KWNU90943

Hydrangea serrata f. acuminata (Siebold \& Zucc.) E. H. Wilson 산 수국 KWNU90443

Philadelphus tenuifolius Rupr. \& Maxim. 얇은잎고광나무 KWNU90699

Ribes mandshuricum (Maxim.) Kom. 까치밥나무 KWNU90444

Ribes maximowiczianum Kom. 명자순 KWNU91251

Rodgersia podophylla A. Gray 도깨비부채 KWNU92122

Saxifraga fortunei var. incisolobata (Engl. \& Irmsch.) Nakai 바위 떡풀 KWNU90944

Rosaceae 장미과

Agrimonia coreana Nakai 산짚신나물 KWNU91255

Agrimonia pilosa Ledeb. 짚신나물 KWNU91028

Crataegus pinnatifida Bunge 산사나무 KWNU91027

Duchesnea indica (Andr.) Focke 뱀딸기 KWNU91249

Geum aleppicum Jacq. 큰뱀무 KWNU91024

Kerria japonica f. pleniflora (Witte) Rehder 죽단화(cult.) KWNU91077

Malus baccata (L.) Borkh. 야광나무 KWNU92700 
Appendix 1. Continued.

\begin{tabular}{|c|}
\hline Scientific name/Korean name/Voucher number \\
\hline Potentilla anemonefolia Lehm. 가락지나물 KWNU91023 \\
\hline Potentilla chinensis Ser. 딱지꽃 KWNU91074 \\
\hline Potentilla cryptotaeniae Maxim. 물양지꽃 KWNU91072 \\
\hline Potentilla dickinsii Franch. \& Sav. 돌양지꽃 KWNU92520 \\
\hline Potentilla fragarioides var. major Maxim. 양지꽃 KWNU91020 \\
\hline Potentilla freyniana Bornm. 세잎양지꽃 KWNU91302 \\
\hline Prunus padus L. 귀룽나무 KWNU91018 \\
\hline Prunus persica (L.) Batsch 복사나무(cult.) KWNU91070 \\
\hline $\begin{array}{l}\text { Prunus serrulata var. pubescens (Makino) Nakai 잔털벚나무 } \\
\text { KWNU91017 }\end{array}$ \\
\hline Rosa multiflora Thunb. 찔레꽃 KWNU93405 \\
\hline Rubus coreanus Miq. 복분자딸기 KWNU91016 \\
\hline Rubus crataegifolius Bunge 산딸기 KWNU91068 \\
\hline Rubus oldhamii Miq. 줄딸기 KWNU91297 \\
\hline Rubus parvifolius L. 멍석딸기 KWNU92771 \\
\hline Rubus phoenicolasius Maxim. 곰딸기 KWNU91014 \\
\hline Sanguisorba officinalis L. 오이풀 KWNU91013 \\
\hline Sorbus commixta Hedl. 마가목 KWNU92668 \\
\hline Spiraea prunifolia f. simpliciflora Nakai 조팝나무 KWNU91065 \\
\hline Spiraea salicifolia L. 꼬리조팝나무 KWNU92671 \\
\hline Stephanandra incisa (Thunb.) Zabel 국수나무 KWNU91009 \\
\hline Leguminosae 콩과 \\
\hline Amorpha fruticosa L. 족제비싸리(cult.) KWNU91273 \\
\hline $\begin{array}{l}\text { Amphicarpaea bracteata subsp. edgeworthii (Benth.) H. Ohashi 새 } \\
\text { 콩 KWNU91272 }\end{array}$ \\
\hline Chamaecrista nomame (Siebold) H. Ohashi 차풀 KWNU90993 \\
\hline $\begin{array}{l}\text { Desmodium podocarpum var. oxyphyllum (DC.) H. Ohashi 도둑놈 } \\
\text { 의갈고리 KWNU92661 }\end{array}$ \\
\hline Glycine soja Siebold \& Zucc. 돌콩 KWNU91036 \\
\hline Kummerowia striata (Thunb.) Schindl. 매듭풀 KWNU91267 \\
\hline Lathyrus davidii Hance 활량나물 KWNU91480 \\
\hline Lespedeza bicolor Turcz. 싸리 KWNU91264 \\
\hline Lespedeza cuneata G.Don 비수리 KWNU92767 \\
\hline Lespedeza cyrtobotrya Miq. 참싸리 KWNU91263 \\
\hline Lespedeza maximowiczii C. K. Schneid. 조록싸리 KWNU91032 \\
\hline $\begin{array}{l}\text { Lespedeza maximowiczii var. tomentella Nakai 털조록싸리 } \\
\text { KWNU90989 }\end{array}$ \\
\hline Lespedeza x nakaii T. B. Lee 꽃참싸리 KWNU91004 \\
\hline Lespedeza x schindleri T. B. Lee 잡싸리 KWNU91260 \\
\hline Maackia amurensis Rupr. 다릅나무 KWNU91284 \\
\hline Melilotus alba Medicus ex Desv. 흰전동싸리 KWNU91473 \\
\hline
\end{tabular}

Appendix 1. Continued.

\begin{tabular}{|c|}
\hline Scientific name/Korean name/Voucher number \\
\hline Pueraria lobata (Willd.) Ohwi 칡 KWNU91001 \\
\hline Robinia pseudoacacia L. 아까시나무(cult.) KWNU91000 \\
\hline Sophora flavescens Solander ex Aiton 고삼 KWNU90999 \\
\hline Trifolium repens L. 토끼풀 KWNU91279 \\
\hline Vicia amurensis Oett. 벌완두 KWNU90995 \\
\hline Vicia pseudo-orobus Fisch. \& C. A. Mey. 큰등갈퀴 KWNU91277 \\
\hline Vicia unijuga A. Braun 나비나물 KWNU91044 \\
\hline $\begin{array}{l}\text { Vigna angularis var. nipponensis (Ohwi) Ohwi \& H. Ohashi 새팥 } \\
\text { KWNU92293 }\end{array}$ \\
\hline Wisteria floribunda (Willd.) DC. 등(cult.) KWNU92765 \\
\hline Oxalidaceae 괭이밥과 \\
\hline Oxalis obtriangulata Maxim. 큰괭이밥 KWNU90960 \\
\hline Oxalis stricta L. 선괭이밥 KWNU90983 \\
\hline Geraniaceae 쥐손이풀과 \\
\hline Geranium sibiricum L. 쥐손이풀 KWNU93394 \\
\hline Euphorbiaceae 대극과 \\
\hline Acalypha australis L. 깨풀 KWNU92680 \\
\hline Euphorbia supina Raf. 애기땅빈대 KWNU92758 \\
\hline Securinega suffruticosa (Pall.) Rehder 광대싸리 KWNU90933 \\
\hline Rutaceae 운향과 \\
\hline Zanthoxylum schinifolium Siebold \& Zucc. 산초나무 KWNU90703 \\
\hline Simaroubaceae 소태나무과 \\
\hline Ailanthus altissima (Mill.) Swingle 가죽나무(cult.) KWNU85605 \\
\hline Picrasma quassioides (D. Don) Benn. 소태나무 KWNU90702 \\
\hline Polygalaceae 원지과 \\
\hline Polygala japonica Houtt. 애기풀 KWNU90402 \\
\hline Anacardiaceae 옻나무과 \\
\hline Rhus javanica L. 붉나무 KWNU90795 \\
\hline Aceraceae 단풍나무과 \\
\hline $\begin{array}{l}\text { Acer pictum subsp. mono (Maxim.) Ohashi 고로쇠나무 } \\
\text { KWNU90867 }\end{array}$ \\
\hline Acer pseudosieboldianum (Pax) Kom. 당단풍나무 KWNU90865 \\
\hline $\begin{array}{l}\text { Acer tataricum subsp. ginnala (Maxim.) Wesm. 신나무 } \\
\text { KWNU90574 }\end{array}$ \\
\hline Acer triflorum Kom. 복자기 KWNU90862 \\
\hline Balsaminaceae 봉선화과 \\
\hline Impatiens nolitangere L. 노랑물봉선 KWNU90344 \\
\hline Impatiens textori Miq. 물봉선 KWNU90341 \\
\hline Celastraceae 노박덩굴과 \\
\hline Celastrus orbiculatus Thunb. 노박덩굴 KWNU90536 \\
\hline Euonymus alatus (Thunb.) Siebold 화살나무 KWNU90078 \\
\hline
\end{tabular}


Appendix 1. Continued.

\begin{tabular}{|c|c|}
\hline Scientific name/Korean name/Voucher num & \\
\hline $\begin{array}{l}\text { Euonymus alatus f. ciliatodentatus (Franch. \& Sav.) H } \\
\text { 나무 KWNU90663 }\end{array}$ & iyama 회잎 \\
\hline Tripterygium regelii Sprague \& Takeda 미역줄나무 K & WNU90494 \\
\hline Staphyleaceae 고추나무과 & \\
\hline Staphylea bumalda DC. 고추나무 KWNU90665 & \\
\hline Buxaceae 회양목과 & \\
\hline Buxus koreana Nakai ex Chung \& al. 회양목(cult.) K & NNU90666 \\
\hline Vitaceae 포도과 & \\
\hline $\begin{array}{l}\text { Ampelopsis brevipedunculata f. ciliata (Nakai) T. B. I } \\
\text { KWNU90498 }\end{array}$ & ee 털개머루 \\
\hline $\begin{array}{l}\text { Parthenocissus tricuspidata (Siebold \& Zucc.) Planch } \\
\text { KWNU90624 }\end{array}$ & 담쟁이덩굴 \\
\hline Vitis coignetiae Pulliat ex Planch. 머루 KWNU90667 & \\
\hline Tiliaceae 피나무과 & \\
\hline Tilia mandshurica Rupr. \& Maxim. 찰피나무 $\mathrm{KWNL}$ & 91597 \\
\hline Sterculiaceae 벽오동과 & \\
\hline Corchoropsis tomentosa (Thunb.) Makino 수까치깨 $\mathrm{I}$ & WNU91554 \\
\hline Violaceae 제비꽃과 & \\
\hline Viola acuminata Ledeb. 졸방제비꽃 KWNU91520 & \\
\hline $\begin{array}{l}\text { Viola albida f. takahashii (Makino) W. T. Lee 단풍제 } \\
\text { KWNU91094 }\end{array}$ & \\
\hline Viola albida Palib. 태백제비꽃 KWNU91093 & \\
\hline $\begin{array}{l}\text { Viola albida var. chaerophylloides (Regel) F. Maek. ex } \\
\text { 제비꽃 KWNU91441 }\end{array}$ & Hara 남산 \\
\hline Viola collina Besser 둥근털제비꽃 KWNU91517 & \\
\hline Viola diamantiaca Nakai 금강제비꽃 KWNU91439 & \\
\hline Viola hirtipes S.Moore 흰털제비꽃 KWNU91091 & \\
\hline Viola japonica Langsd. ex Ging. 왜제비꽃 KWNU91 & \\
\hline Viola keiskei Miq. 잔털제비꽃 KWNU91515 & \\
\hline Viola mandshurica W. Becker 제비꽃 KWNU91364 & \\
\hline Viola orientalis (Maxim.) W. Becker 노랑제비꽃 KW & NU91513 \\
\hline Viola phalacrocarpa Maxim. 털제비꽃 KWNU91089 & \\
\hline Viola rossii Hemsl. 고깔제비꽃 KWNU91088 & \\
\hline $\begin{array}{l}\text { Viola tokubuchiana var. takedana (Makino) F. Maek. } \\
\text { 꽃 KWNU91087 }\end{array}$ & 긴둥뫼제비 \\
\hline $\begin{array}{l}\text { Viola tokubuchiana var. takedana f. variegata F. Maek } \\
\text { 비꽃 KWNU91086 }\end{array}$ & 줄민둥뫼제 \\
\hline Viola variegata Fisch. ex Link 알록제비꽃 KWNU91 & 507 \\
\hline Viola verecunda A. Gray 콩제비꽃 KWNU91083 & \\
\hline Lythraceae 부처꽃과 & \\
\hline Rotala indica (Willd.) Koehne 마디꽃 KWNU90425 & \\
\hline Onagraceae 바늘꽃과 & \\
\hline
\end{tabular}

Appendix 1. Continued.

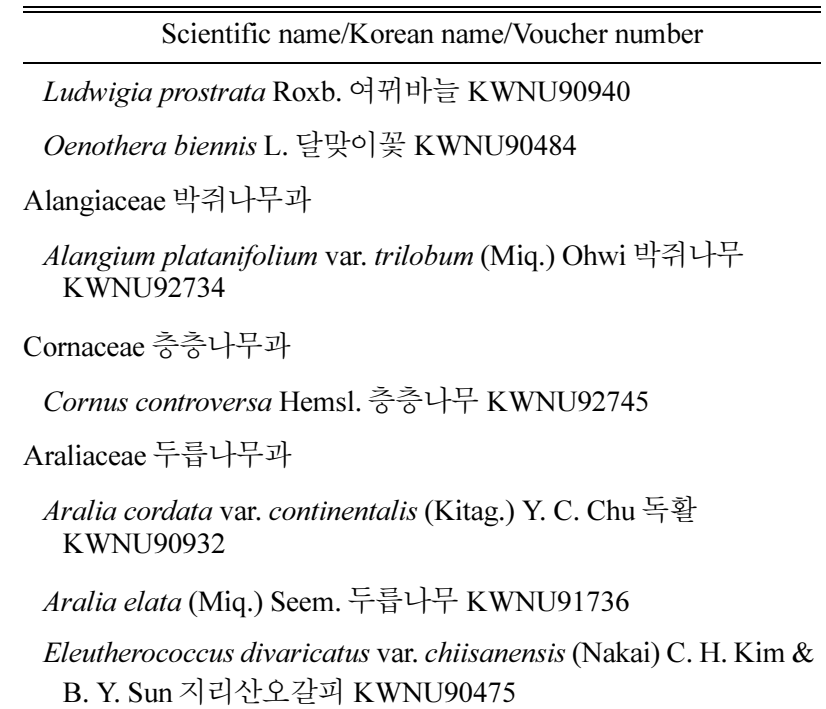

Umbelliferae 산형과

Angelica dahurica (Fisch. ex Hoffm.) Benth. \& Hook. f. ex Franch. \& Sav. 구릿대 KWNU90337

Angelica decursiva (Miq.) Franch. \& Sav. 바디나물 KWNU90255 Angelica genuflexa Nutt. ex Torr. \& A. Gray 왜천궁 KWNU90223 Angelica polymorpha Maxim. 궁궁이 KWNU90274

Oenanthe javanica (Blume) DC. 미나리 KWNU90670

Osmorhiza aristata (Thunb.) Makino \& Yabe 긴사상자 KWNU90363

Ostericum grosseserratum (Maxim.) Kitag. 신감채 KWNU90413

Peucedanum terebinthaceum (Fisch.) Fisch. ex DC. 기름나물 KWNU92525

Pimpinella brachycarpa (Kom.) Nakai 참나물 KWNU90330

Sanicula chinensis Bunge 참반디 KWNU90253

Sillaphyton podagraria (H. Boissieu) Pimenov 덕우기름나물 KWNU90332

Torilis japonica (Houtt.) DC. 사상자 KWNU90276

Pyrolaceae 노루발과

Pyrola japonica Klenze ex Alef. 노루발 KWNU90495

Ericaceae 진달래과

Rhododendron mucronulatum Turcz. 진달래 KWNU90501

Rhododendron mucronulatum var. ciliatum Nakai 털진달래 KWNU92236

Rhododendron schlippenbachii Maxim. 철쭉 KWNU90630

Vaccinium hirtum var. koreanum (Nakai) Kitam. 산앵도나무 KWNU90673

Primulaceae 앵초과

Androsace umbellata (Lour.) Merr. 봄맞이 KWNU91389

Lysimachia clethroides Duby 큰까치수염 KWNU91458 
Appendix 1. Continued.

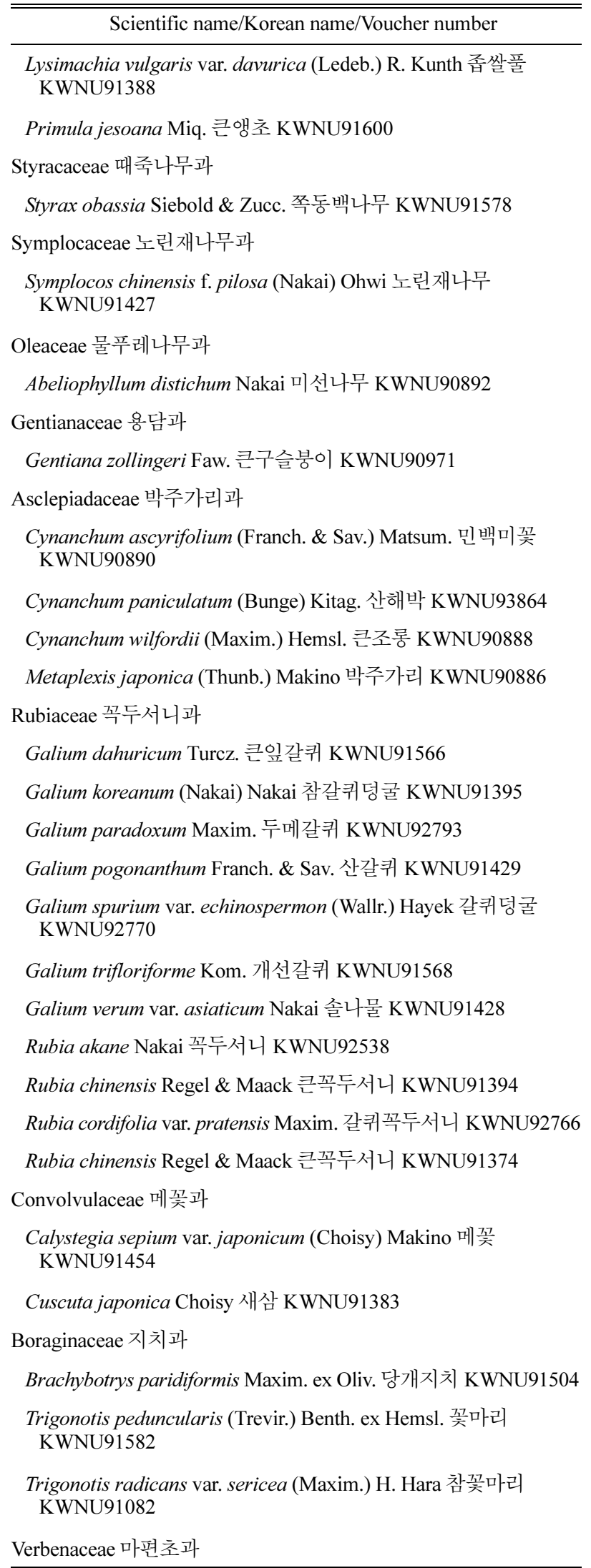

Appendix 1. Continued.

\begin{tabular}{|c|}
\hline Scientific name/Korean name/Voucher number \\
\hline Callicarpa japonica Thunb. 작살나무 KWNU90897 \\
\hline Labiatae 꿀풀과 \\
\hline Agastache rugosa (Fisch. \& Mey.) Kuntze 배초향 KWNU90446 \\
\hline Clinopodium micranthum (Regel) Hara 두메층층이 KWNU90882 \\
\hline Elsholtzia ciliata (Thunb.) Hyl. 향유 KWNU90879 \\
\hline Isodon inflexus (Thunb.) Kudo 산박하 KWNU90874 \\
\hline Isodon japonicus (Burm.) Hara 방아풀 KWNU90456 \\
\hline $\begin{array}{l}\text { Lamium album var. barbatum (Siebold \& Zucc.) Franch. \& Sav. 광 } \\
\text { 대수염 KWNU93402 }\end{array}$ \\
\hline Lamium amplexicaule L. 광대나물 KWNU84986 \\
\hline Leonurus japonicus Houtt. 익모초 KWNU92678 \\
\hline Lycopus lucidus Turcz. ex Benth. 쉽싸리 KWNU90454 \\
\hline Meehania urticifolia (Miq.) Makino 벌깨덩굴 KWNU90959 \\
\hline $\begin{array}{l}\text { Mosla dianthera (Buch.-Ham. ex Roxb.) ex Maxim. 쥐깨풀 } \\
\text { KWNU90453 }\end{array}$ \\
\hline Mosla punctulata (J. F. Gmelin) Nakai 들깨풀 KWNU90451 \\
\hline Prunella vulgaris var. lilacina Nakai 꿀풀 KWNU90449 \\
\hline $\begin{array}{l}\text { Scutellaria pekinensis var. transitra (Makino) H. Hara 산골무꽃 } \\
\text { KWNU90447 }\end{array}$ \\
\hline Stachys japonica Miq. 석잠풀 KWNU90953 \\
\hline Solanaceae 가지과 \\
\hline Scopolia japonica Maxim. 미치광이풀 KWNU90711 \\
\hline Solanum americanum Mill. 미국까마중 KWNU90691 \\
\hline Solanum nigrum L. 까마중 KWNU92746 \\
\hline Scrophulariaceae 현삼과 \\
\hline Lindernia procumbens (Krock.) Borbas 밭뚝외풀 KWNU90910 \\
\hline Mazus pumilus (Burm.f.) Steenis 주름잎 KWNU90907 \\
\hline Melampyrum roseum Maxim. 꽃며느리밥풀 KWNU90904 \\
\hline $\begin{array}{l}\text { Phtheirospermum japonicum (Thunb.) Kanitz 나도송이풀 } \\
\text { KWNU90901 }\end{array}$ \\
\hline Veronica arvensis L. 선개불알풀 KWNU90900 \\
\hline Bignoniaceae 능소화과 \\
\hline $\begin{array}{l}\text { Campsis grandifolia (Thunb.) K. Schum. 능소화(cult.) } \\
\text { KWNU92731 }\end{array}$ \\
\hline Phrymaceae 파리풀과 \\
\hline Phryma leptostachya var. asiatica H. Hara 파리풀 KWNU90369 \\
\hline Plantaginaceae 질경이과 \\
\hline Plantago asiatica L. 질경이 KWNU91387 \\
\hline Caprifoliaceae 인동과 \\
\hline Lonicera japonica Thunb. 인동덩굴 KWNU90583 \\
\hline Lonicera praeflorens Batalin 올괴불나무 KWNU90870 \\
\hline
\end{tabular}


Appendix 1. Continued.

\begin{tabular}{|c|}
\hline Scientific name/Korean name/Voucher number \\
\hline $\begin{array}{l}\text { Sambucus sieboldiana var. miquelii (Nakai) Hara 지렁쿠나무 } \\
\text { KWNU90606 }\end{array}$ \\
\hline Weigela florida (Bunge) A. DC. 붉은병꽃나무 KWNU90804 \\
\hline Weigela subsessilis (Nakai) L. H. Bailey 병꽃나무 KWNU90802 \\
\hline Adoxaceae 연복초과 \\
\hline Adoxa moschatellina L. 연복초 KWNU90584 \\
\hline Valerianaceae 마타리과 \\
\hline Patrinia scabiosaefolia Fisch. ex Trevir. 마타리 KWNU90651 \\
\hline Patrinia villosa (Thunb.) Juss. 뚝갈 KWNU92248 \\
\hline Valeriana fauriei Briq. 쥐오줌풀 KWNU90649 \\
\hline Campanulaceae 초롱꽃과 \\
\hline Adenophora verticillata Fisch. 층층잔대 KWNU91078 \\
\hline Asyneuma japonicum (Miq.) Briq. 영아자 KWNU91434 \\
\hline Campanula punctata Lam. 초롱꽃 KWNU91433 \\
\hline Codonopsis lanceolata (Siebold \& Zucc.) Trautv. 더덕 KWNU92753 \\
\hline Lobelia chinensis Lour. 수염가래꽃 KWNU91499 \\
\hline Platycodon grandiflorum (Jacq.) A. DC. 도라지 KWNU92733 \\
\hline $\begin{array}{l}\text { Platycodon grandiflorum f. albiflorum (Honda) H. Hara 백도라지 } \\
\text { (cult.) KWNU93396 }\end{array}$ \\
\hline Compositae 국화과 \\
\hline Adenocaulon himalaicum Edgew. 멸가치 KWNU90686 \\
\hline Ainsliaea acerifolia Sch. Bip. 단풍취 KWNU93393 \\
\hline Ambrosia artemisiifolia L. 돼지풀 KWNU90556 \\
\hline Artemisia capillaris Thunb. 사철쑥 KWNU90662 \\
\hline Artemisia gmelini Weber ex Stechm. 더위지기 KWNU90618 \\
\hline Artemisia japonica Thunb. 제비쑥 KWNU90526 \\
\hline Artemisia keiskeana Miq. 맑은대쑥 KWNU90660 \\
\hline Artemisia princeps Pamp. 쑥 KWNU90659 \\
\hline Artemisia stolonifera (Maxim.) Kom. 넓은잎외잎쑥 KWNU90658 \\
\hline Aster ageratoides Turcz. 까실쑥부쟁이 KWNU90617 \\
\hline Aster incisus Fisch. 가새쑥부쟁이 KWNU90657 \\
\hline Aster meyendorfii (Regel \& Maack) Voss 개쑥부쟁이 KWNU90641 \\
\hline Aster pilosus Willd. 미국쑥부쟁이 KWNU90615 \\
\hline Aster scaber Thunb. 참취 KWNU90654 \\
\hline Aster tataricus L. f. 개미취 KWNU90517 \\
\hline Atractylodes ovata (Thunb.) DC. 삽주 KWNU90557 \\
\hline Bidens bipinnata L. 도깨비바늘 KWNU92751 \\
\hline Bidens frondosa L. 미국가막사리 KWNU90267 \\
\hline $\begin{array}{l}\text { Bidens radiata var. pinnatifida (Turcz. ex DC.) Kitam. 구와가막사 } \\
\text { 리 KWNU90559 }\end{array}$ \\
\hline Bidens tripartita L. 가막사리 KWNU90560 \\
\hline
\end{tabular}

Appendix 1. Continued.

\begin{tabular}{|c|}
\hline Scientific name/Korean name/Voucher number \\
\hline Carduus crispus L. 지느러미엉겅퀴 KWNU90561 \\
\hline Centipeda minima (L.) A. Br. \& Asch. 중대가리풀 KWNU90562 \\
\hline $\begin{array}{l}\text { Cirsium japonicum var. maackii (Maxim.) Matsum. 엉겅퀴 } \\
\text { KWNU90266 }\end{array}$ \\
\hline Cirsium pendulum Fisch. ex DC. 큰엉겅퀴 KWNU90309 \\
\hline Cirsium setidens (Dunn) Nakai 고려엉겅퀴 KWNU92242 \\
\hline Conyza canadensis (L.) Cronquist 망초 KWNU90833 \\
\hline Cosmos bipinnatus Cav. 코스모스(cult.) KWNU92736 \\
\hline $\begin{array}{l}\text { Crepidiastrum denticulatum (Houtt.) Pak \& Kawano 이고들 빼기 } \\
\text { KWNU90814 }\end{array}$ \\
\hline $\begin{array}{l}\text { Crepidiastrum sonchifolium (Bunge) Pak \& Kawano 고들 빼기 } \\
\text { KWNU90764 }\end{array}$ \\
\hline $\begin{array}{l}\text { Dendranthema boreale (Makino) Ling ex Kitam. 산국 } \\
\text { KWNU90765 }\end{array}$ \\
\hline Dendranthema zawadskii (Herb.) Tzvelev 산구절초 KWNU92234 \\
\hline Erigeron annuиs (L.) Pers. 개망초 KWNU90838 \\
\hline Erigeron strigosus Muhl. 주걱개망초 KWNU90922 \\
\hline Eupatorium japonicum Thunb. 등골나물 KWNU92535 \\
\hline Galinsoga ciliata (Raf.) S. F. Blake 털별꽃아재비 KWNU90202 \\
\hline Hemistepta lyrata Bunge 지칭개 KWNU90395 \\
\hline Ixeridium dentatum (Thunb.) Tzvelev 씀바귀 KWNU90394 \\
\hline Ixeris polycephala Cass. 벌씀바귀 KWNU90393 \\
\hline Lactuca indica L. 왕고들빼기 KWNU90392 \\
\hline Ligularia fischeri (Ledeb.) Turcz. 곰취 KWNU89577 \\
\hline $\begin{array}{l}\text { Parasenecio auriculata var. matsumurana Nakai 박쥐나물 } \\
\text { KWNU92929 }\end{array}$ \\
\hline Petasites japonicus (Siebold \& Zucc.) Maxim. 머위 KWNU90315 \\
\hline Picris hieracioides var. koreana Kitam. 쇠서나물 KWNU90390 \\
\hline Rudbeckia bicolor Nutt. 원추천인국(cult.) KWNU92749 \\
\hline Saussurea gracilis Maxim. 은분취 KWNU92237 \\
\hline Saussurea grandifolia Maxim. 서덜취 KWNU90240 \\
\hline Sigesbeckia glabrescens (Makino) Makino 진득찰 KWNU90235 \\
\hline $\begin{array}{l}\text { Solidago virgaurea subsp. asiatica Kitam. ex H. Hara 미역취 } \\
\text { KWNU90230 }\end{array}$ \\
\hline Syneilesis palmata (Thunb.) Maxim. 우산나물 KWNU90209 \\
\hline Taraxacum officinale Weber 서양민들레 KWNU90287 \\
\hline Taraxacum platycarpum Dahlst. 민들레 KWNU90286 \\
\hline Youngia japonica (L.) DC. 뽀리뱅이 KWNU90285 \\
\hline Alismataceae 택사과 \\
\hline Sagittaria aginashi Makino 보풀 KWNU91385 \\
\hline Liliaceae 백합과 \\
\hline Allium macrostemon Bunge 산달래 KWNU92725 \\
\hline
\end{tabular}


Appendix 1. Continued.

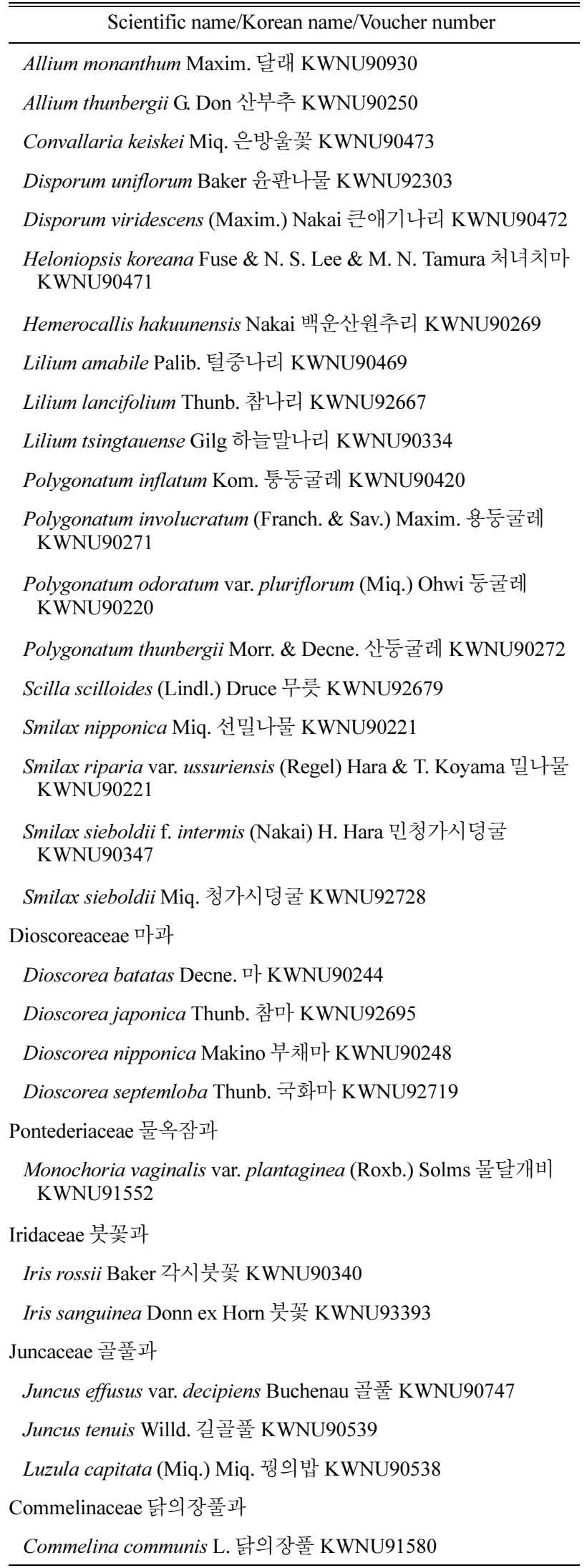

Appendix 1. Continued.

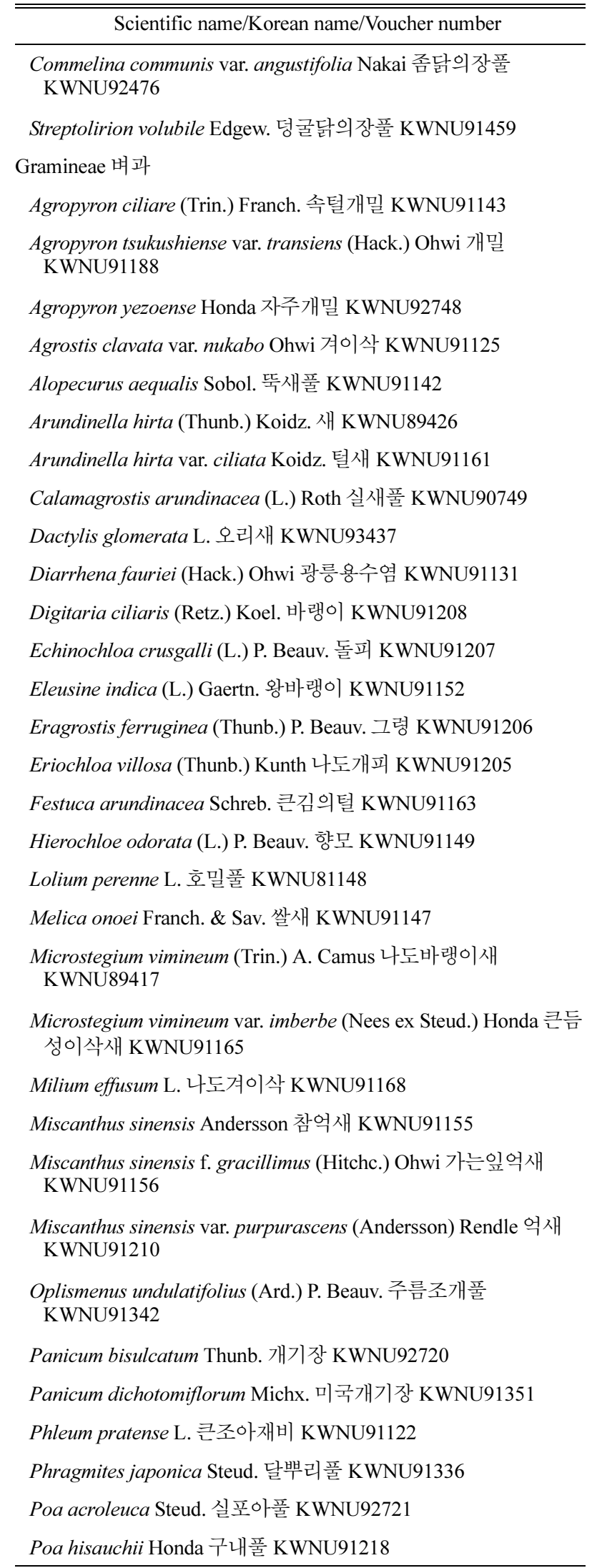


Appendix 1. Continued.

Scientific name/Korean name/Voucher number

Poa sphondylodes Trin. 포아풀 KWNU91361

Setaria $\times$ pycnocoma (Steud.) Henrard ex Nakai 수강아지풀 KWNU91177

Setaria faberii Herrm. 가을강아지풀 KWNU91213

Setaria glauca (L.) P. Beauv. 금강아지풀 KWNU91180

Setaria viridis (L.) P. Beauv. 강아지풀 KWNU91160

Spodiopogon sibiricus Trin. 큰기름새 KWNU91117

Trisetum bifidum (Thunb.) Ohwi 잠자리피 KWNU91355

Araceae 천남성과

Arisaema amurense f. serratum (Nakai) Kitag. 천남성 KWNU91574

Arisaema peninsulae Nakai 점박이천남성 KWNU93403

Pinellia ternata (Thunb.) Breitenb. 반하 KWNU92760

Cyperaceae 사초과

Carex filipes Franch. \& Sav. 낚시사초 KWNU92688

Carex glabrescens Ohwi 곱슬사초 KWNU90066

Carex hakonensis Franch. \& Sav. 애기바늘사초 KWNU90212

Carex japonica Thunb. 개찌버리사초 KWNU90830

Carex laevissima Nakai 애괭이사초 KWNU90758

Carex leiorhyncha C. A. Mey. 산괭이사초 KWNU90829

Carex maackii Maxim. 타래사초 KWNU90687

Carex neurocarpa Maxim. 괭이사초 KWNU90742

Carex phacota Spreng. 비늘사초 KWNU90740

Carex polyschoena H. Lév. \& Vaniot 가지청사초 KWNU90214

Carex siderosticta Hance 대사초 KWNU90755

Cyperus amuricus Maxim. 방동사니 KWNU92673

Cyperus difformis L. 알방동사니 KWNU90753

Cyperus hakonensis Franch. \& Sav. 병아리방동사니 KWNU90826

Cyperus microiria Steud. 금방동사니 KWNU90326

Cyperus orthostachyus Franch. \& Sav. 쇠방동사니 KWNU90752

Kyllinga brevifolia Rottb. 파대가리 KWNU90825

Lipocarpha microcephala (R. Br.) Kunth 세 대가리 KWNU90543

Scirpus juncoides var. hotarui (Ohwi) Ohwi 올챙이고 랭이 KWNU89178

Scirpus wallichii Nees 수원고랭이 KWNU90023

Orchidaceae 난초과

Cephalanthera longibracteata Blume 은대난초 KWNU91007

Liparis kumokiri F. Maek. 옥잠난초 KWNU91295 